\title{
ANALISIS SOAL MATEMATIKA BERBASIS HOTS DAN KEMAMPUAN PEMECAHAN MASALAH SISWA
}

\section{ANALYSIS OF MATHEMATICS PROBLEMS BASED ON HOTS AND STUDENTS' PROBLEM-SOLVING ABILITY}

\author{
Nur Aisyah'1), Sitti Mania'), Muliaty Amin'3), Fitriani Nur'), Andi Dian Angriani ${ }^{5)}$ \\ 1,2,3,4,5) Universitas Islam Negeri Alauddin Makassar \\ nur.aisyah@gmail.com ${ }^{1}$, , sitti.mania@uin-alauddin.ac.id ${ }^{2}$, muliaty.amin@uin-alauddin.ac.id ${ }^{3)}$, \\ fitrianinur@uin-alauddin.ac.id ${ }^{4}$, dian.angriani@uin-alauddin.ac.id(5)
}

\begin{abstract}
Abstrak
Kemampuan pemecahan masalah menjadi target kemampuan dalam matematika sehingga guru dituntut untuk menyediakan soal yang dapat melatih kemampuan berpikir tingkat tinggi dan kemampuan pemecahan masalah matematis siswa. Tujuan dari penelitian ini adalah menganalisis soal buatan guru dan tingkat kemampuan pemecahan masalah siswa dalam menyelesaikan soal HOTS. Jenis penelitian ini adalah penelitian analisis dokumen. Adapun subjek penelitian ini yaitu guru dan siswa kelas VIII SMP Pondok Pesantren Ulul Albab Makassar. Peneliti mengumpulkan soal latihan, soal ulangan harian, soal akhir semester, serta jawaban siswa. Soal dianalisis sesuai dengan taksonomi kognitif Bloom. Selanjutnya dilakukan reduksi data, penyajian data, dan penarikan kesimpulan. Hasil analisis menunjukkan soal-soal tersebut didominasi pada ranah kognitif pemahaman, pengetahuan, aplikasi, dan analisis. Kemampuan pemecahan masalah siswa dalam mengerjakan soal HOTS sebesar $70 \%$ berada pada kategori kurang, $15 \%$ berada pada kategori cukup, $20 \%$ pada kategori baik, dan $0 \%$ pada kategori sangat tinggi. Temuan lain dari penelitian ini yaitu ketidakmampuan siswa dalam pemecahan masalah yaitu merencanakan penyelesaian masalah, melakukan penyelesaian masalah dan membuat review atas rencana pemecahan masalah. Penyebabnya antara lain siswa tidak rutin menyelesaikan soal HOTS, kekhawatiran guru terhadap siswa kalau tidak mampu menjawab soal-soal matematika dan guru kurang memahami bentuk soal HOTS. Dengan demikian, melalui penelitian ini diharapkan guru dapat berlatih untuk membuat soal-soal matematika tipe HOTS ataupun diselenggarakannya pelatihan-pelatihan cara membuat soal-soal matematika tipe HOTS.
\end{abstract}

Kata Kunci: keterampilan berpikir tingkat tinggi, kemampuan pemecahan masalah, soal matematika

\begin{abstract}
Problem solving ability becomes the target of ability in mathematics so that teachers are required to provide questions that can train students' higher-order thinking skills and mathematical problem solving abilities. The purpose of this study was to analyze teachermade questions and the level of students' problem-solving abilities in solving HOTS questions. This type of research is document analysis research. The subjects of this study were teachers and students of class VIII SMP Pondok Pesantren Ulul Albab Makassar. Researchers collected practice questions, daily test questions, end of semester questions, and student answers. The questions were analyzed according to Bloom's cognitive taxonomy. Furthermore, data reduction, data presentation, and conclusion drawing are carried out. The results of the analysis show that these questions are dominated by the cognitive domains of understanding, knowledge, application, and analysis. The problem solving ability of students in working on HOTS questions is $70 \%$ in the less category, $15 \%$ in the sufficient category, $20 \%$ in the good
\end{abstract}


category, and 0\% in the very high category. Another finding from this study is the students' inability to solve problems, namely planning problem solving, problem solving and reviewing problem solving plans. The causes include students not routinely solving HOTS questions, teachers' concerns about students if they are not able to answer mathematics questions and teachers do not understand the form of HOTS questions. Thus, through this research, it is hoped that teachers can practice making HOTS-type mathematics problems or holding trainings on how to make HOTS-type mathematics problems.

Keywords: higher order thinking skills, problem solving ability, mathematics problems

How to Cite: Aisyah, N., Mania, S., Amin, M., Nur, F., \& Angriani, A.D. (2021). Analisis soal matematika berbasis HOTS dan kemampuan pemecahan masalah siswa. Al asma: Journal of Islamic Education, 3(2), 223-231.

\section{PENDAHULUAN}

Pendidikan adalah proses pengembangan daya nalar, keterampilan, dan moralitas kehidupan pada potensi yang dimiliki oleh setiap manusia. Salah satu upaya untuk menggali potensi tersebut adalah dengan diterapkannya pembelajaran matematika di sekolah. Chabibah, Siswanah, dan Tsani (2019) mengungkapkan bahwa standar proses dalam pembelajaran matematika menurut The National Council of Teachers of Mathematics meliputi problem-solving, reasoning and proof, communication, connection, dan representation. Dari lima standar pembelajaran matematika, pemecahan masalah menjadi salah satu standar internasional yang harus dilampaui siswa untuk menghadapi tantangan-tantangan bagi generasi sekarang.

Riati dan Farida (2017) menyatakan kemampuan pemecahan masalah matematika adalah kemampuan mengidentifikasi unsur-unsur yang diketahui, ditanyakan dan kecukupan unsur yang diperlukan, mampu membuat atau menyusun model matematika, dapat memilih dan mengembangkan strategi pemecahan, mampu menjelaskan dan memeriksa kebenaran jawaban yang diperoleh. Adapun indikator yang digunakan dalam pemecahan masalah menurut Polya, yaitu (1) memahami masalah, (2) membuat rencana pemecahan masalah, (3) menyelesaikan rencana masalah, dan (4) memeriksa kembali hasil yang diperoleh. Langkah-langkah dalam proses pemecahan masalah yang dikemukan Polya cukup sederhana, aktivitas-aktivitas pada setiap langkah cukup jelas dan langkahlangkah tersebut telah lazim digunakan dalam memecahkan masalah matematika (Pradani \& Ilman, 2019).

Kemampuan pemecahan masalah merupakan kemampuan yang menjadi target pembelajaran matematika dan terukur. Pengukuran kemampuan pemecahan masalah didasarkan pada proses yang dilakukan oleh siswa (Azizah, Zaenuri, \& Kharisudin, 2020). Untuk mengukur kemampuan pemecahan masalah siswa maka diperlukan suatu soal yang dapat mengukur Higher Order Thinking Skills (HOTS) siswa. Menurut Hidayati (2017) peran penting keterampilan berpikir tingkat tinggi dalam pembelajaran matematika terletak pada proses pembelajaran. Siswa akan terbiasa berpikir kritis dan kreatif baik dalam pengambilan keputusan dan pemecahan masalah yang berkaitan dengan menganalisis, mengevaluasi dan mencipta. Amalia dan Pujiastuti (2020) mengemukakan bahwa tujuan pembelajaran matematika adalah dapat memiliki kemampuan pemecahan masalah yang baik. Tentunya dalam memecahkan suatu masalah memerlukan 
kemampuan berpikir tingkat tinggi. Kemampuan pemecahan masalah matematis siswa perlu diketahui melalui pengerjaan suatu soal yang merangsang kemampuan berpikir tingkat tinggi siswa. Kemampuan berpikir tingkat tinggi adalah proses berpikir siswa dalam level kognitif yang lebih tinggi, dikembangkan dalam taksonomi pembelajaran (Wardani, 2020). Dengan demikian, untuk melatih kemampuan pemecahan masalah matematis siswa guru dituntut untuk menyediakan soal-soal yang dapat mengembangkan kemampuan berpikir tingkat tinggi siswa. Sehingga melalui peningkatan kemampuan berpikir tingkat tinggi, siswa dapat melatih kemampuan pemecahan masalah matematisnya.

Berdasarkan hasil wawancara yang dilakukan pada Pondok Pesantren Ulul Albab, guru mata pelajaran telah mengembangkan beberapa soal sebagai instrument evaluasi siswa khususnya untuk melihat seberapa jauh kemampuan pemecahan masalah matematis siswa. Soal yang dikembangkan diklaim bahwa dapat merangsang kemampuan berpikir tingkat tinggi siswa. Menurut Fauzan, Gani, \& Syukri (2017) dengan berpikir tingkat tinggi maka siswa dapat memecahkan masalah dengan baik. Berangkat dari pernyataan tersebut dapat disadari bahwa pentingnya mengetahui apakah instrumen berupa soal yang dikembangkan dapat merangsang kemampuan berpikir tingkat tinggi siswa.

Peneliti sebelumnya telah banyak melakukan analisis kemampuan pemecahan masalah matematis siswa, yaitu Rame dan Afri (2020) melakukan penelitian untuk mengetahui kemampuan pemecahan masalah matematis siswa terutama dalam menyelesaikan soal materi barisan dan deret. Sapitri, Utami, dan Mariyam (2019) menganalisis kemampuan pemecahan masalah matematis siswa melalui soal open ended khususnya pada materi lingkaran. Mita, Tambunan, \& Izzati (2019) menganalisis kemampuan pemecahan masalah matematis siswa melalui soal berbasis PISA. Beberapa penelitian yang telah disebutkan, pada umumnya melakukan analisis kemampuan pemecahan masalah matematis, namun tidak mendefinisikan secara jelas apakah soal-soal tersebut dapat merangsang HOTS siswa. Oleh karena itu, pada penelitian ini difokuskan untuk menganalisis soal buatan guru dan kemampuan pemecahan masalah matematis siswa dalam menyelesaikan soal HOTS.

\section{METODE PENELITIAN}

Penelitian ini menggunakan pendekatan kualitatif deskriptif dengan jenis penelitian analisis dokumen. Dalam penelitian kualitatif, yang menjadi instrument adalah peneliti sendiri. Subjek penelitian ini yaitu guru dan siswa kelas VIII SMP Pondok Pesantren Ulul Albab Makassar yang masuk pada aspek HOTS (Higher Order Thinking Skill). Adapun teknik pengumpulan data yang dilakukan pada penelitian ini adalah wawancara dan analisis dokumen. Pengumpulan data dilakukan dengan mengumpulkan soal latihan, soal ulangan harian, soal akhir semester, serta jawaban siswa dan wawancara. Tes yang dimaksudkan berbasis HOTS yaitu soal yang memiliki level C4, C5, dan C6 pada taksonomi kognitif Bloom. Selanjutnya data yang terkumpul dianalisis dengan menggunakan teknik analisis data kualitatif yang bersifat induktif, yaitu suatu analsis berdasarkan data yang diperoleh dalam pengumpulan data. 


\section{HASIL DAN PEMBAHASAN}

\section{Deskripsi Hasil Analisis Soal Matematika Berbasis HOTS}

Berikut ini hasil analisis soal-soal matematika buatan guru (teachermade test) meliputi soal latihan, soal ulangan harian dan soal ujian semester. Hasil analisis soal-soal matematika buatan guru berdasarkan kategori soal yang masuk pada aspek HOTS (higher order thinking skill) yang bersifat analisis, evaluasi dan kreasi. Berikut hasil analisis soalsoal buatan guru (teacher-made test). Bentuk soal latihan buatan guru dapat dilihat pada gambar 1 berikut ini.

\section{Ubahlah persamaan $3 x^{2}=2 x-4$ dalam bentuk umum persamaan kuadrat.}

\section{Gambar 1. Soal 1 Buatan Guru}

Hasil analisis: Perintah soal no. 1 adalah mengubah persamaan ke dalam bentuk umum persamaan kuadrat. Menyelesaiakan soal no. 1 diperlukan kemampuan mengenali kembali/mengingat kembali pengetahuan yang telah dipelajari sebelumnya yaitu bentuk umum persamaan kuadrat. Berdasarkan indikator tingkat kognitif taksonomi Bloom revisi, kemampuan untuk mengenali kembali/mengingat kembali pengetahuan yang telah dipelajari sebelumnya memiliki kata operasional mengingat kembali atau mengenali termasuk ke dalam tingkat kognitif C1 (Nursalam, Angriani, Darmawati, Baharuddin, \& Aminuddin (2018).

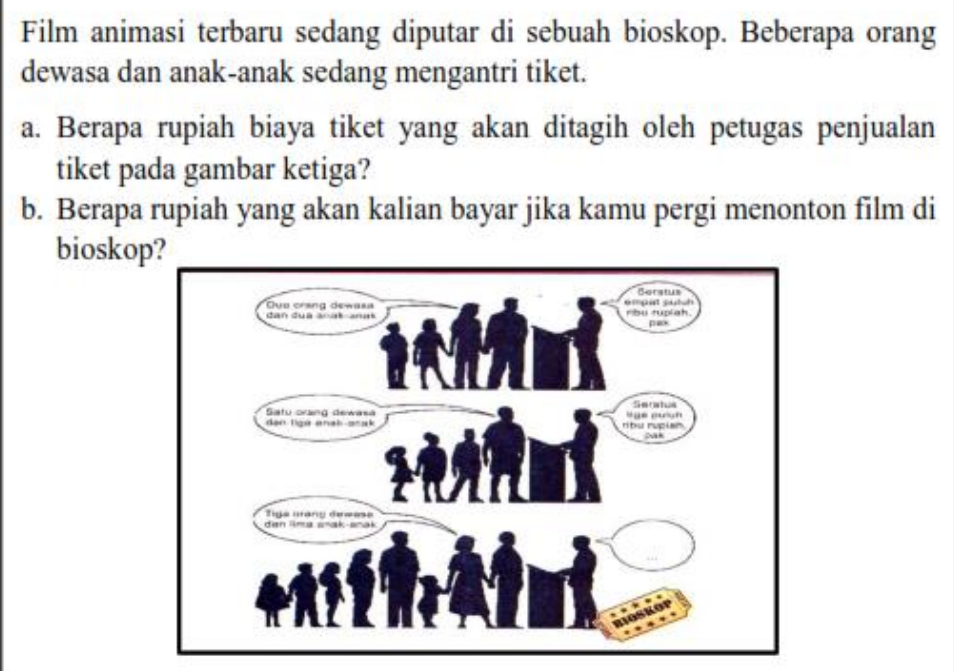

Gambar 2. Soal 2 Buatan Guru

Hasil analisis: perintah soal (a) dan (b) di atas adalah menghitung biaya tiket yang akan ditagih oleh petugas penjualan tiket pada gambar ketiga. Penyelesaian soal tersebut memerlukan kemampuan menggunakan prosedur dalam keadaan tertentu dan memecah mecahkan materi menjadi bagian-bagian penyusunnya dan menentukan hubunganhubungan antarbagian dan hubungan dengan keseluruhan struktur. Kedua kemampuan tersebut memiliki kata operasional mengimplementasi dan mengorganisasi dan tergolong pada tingkat kognitif yaitu C3 dan C4 yaitu mengaplikasi dan menganalisis (Asrul, Ananda, \& Rosnita, 2014). 
Siswa dituntut menyelesaikan soal di atas dengan cara yang kreatif maksudnya proses penyelesaian yang tidak rutin. Berdasarkan indikator tingkat kognitif taksonomi Bloom revisi, memadukan bagian-bagian untuk membentuk sesuatu yang baru misalnya menggunakan proses penyelesaian yang baru merupakan definisi dari kata operasional merencanakan atau membuat dan tergolong pada tingkat C6 yaitu membuat (Intan \& Kuntarto, 2020).

Setelah diperoleh hasil analisis soal di atas kemudian data tersebut dikelompokkan berdasarkan tingkatan kognitif menurut taksonomi Bloom. Hasilnya dapat dilihat pada tabel di bawah ini:

Tabel 1. Rekapitulasi Hasil Analisis Soal Berdasarkan Taksonomi Bloom

\begin{tabular}{|c|c|c|c|c|c|c|c|}
\hline \multirow{2}{*}{ Sumber } & \multirow{2}{*}{$\begin{array}{c}\text { Jumlah } \\
\text { Soal }\end{array}$} & \multicolumn{6}{|c|}{ Dimensi Kognitif Taksonomi Bloom } \\
\hline & & C1 & $\mathrm{C} 2$ & C3 & C4 & C5 & C6 \\
\hline $\begin{array}{l}\text { Soal } \\
\text { Latihan }\end{array}$ & 5 & 3 & 2 & - & - & - & - \\
\hline $\begin{array}{l}\text { Soal } \\
\text { Ulangan } \\
\text { Harian }\end{array}$ & 5 & 2 & 3 & - & - & - & - \\
\hline $\begin{array}{l}\text { Soal Akhir } \\
\text { Semester }\end{array}$ & 8 & 2 & 7 & 1 & - & - & - \\
\hline $\begin{array}{l}\text { Soal } \\
\text { Pemecahan } \\
\text { Masalah } \\
\text { Siwa }\end{array}$ & 3 & 1 & 3 & 3 & 3 & 1 & 3 \\
\hline $\begin{array}{l}\text { Jumlah } \\
\text { Persen }\end{array}$ & ase $^{21}$ & $\begin{array}{c}8 \\
34,3 \%\end{array}$ & $\begin{array}{c}15 \\
33,5 \%\end{array}$ & $\begin{array}{c}4 \\
\mathbf{1 , 8} \%\end{array}$ & $\begin{array}{c}3 \\
1,6 \%\end{array}$ & $\begin{array}{c}1 \\
0,2 \%\end{array}$ & $\begin{array}{c}3 \\
1,6 \%\end{array}$ \\
\hline
\end{tabular}

\section{Deskripsi Hasil Wawancara terhadap Guru Mata Pelajaran Matematika}

Setelah menganalisis bentuk-bentuk soal buatan guru pada soal latihan, ulangan harian dan ulangan semester, selanjutnya diadakan wawancara terhadap guru mata pelajaran matematika sebagai pendukung data yang di peroleh. Berikut dialog wawancara terhadap guru mata pelajaran matematika kelas VIII SMP Pondok Pesantren Ulul Albab Makassar tentang soal buatan guru (teacher-made test) berdasarkan pertanyaan berbasis tingkat tinggi.

Dari hasil analisis wawancara, tampak guru mengutarakan kendala-kendala yang dihadapi dalam membuat soal matematika yang merangsang siswa untuk berpikir tingkat tinggi yaitu siswa kesulitan dalam memahami bahasa soal matematika, kekhawatiran guru pada kemampuan siswa dalam menjawab soal tingkatan C4, C5, dan C6, dan kemampuan tenaga pendidik dalam membuat soal matematika berpikir tingkat tinggi yang sangat kurang dikarenakan belum paham betul bentuk soal matematika yang merangsang siswa untuk berpikir tingkat tinggi. Pertanyaan kedua, guru menjelaskan penyebab kendala yang dihadapi yaitu, tidak adanya pelatihan berupa cara membuat soal matematika pada aspek berpikir tingkat tinggi yang menguji aspek kognitif siswa yaitu menganalisis, mengevaluasi, dan mengkreasi.

Terakhir, guru mengharapkan penggunaan soal matematika berpikir tingkat tinggi dapat digunakan dalam kegiatan evaluasi siswa, walaupun jawaban siswa sekarang agak belum sempurna, diharapkan ketika siswa turun ke masyarakat, siswa dapat 
menyelesaikan permasalahan masyarakat karena di sekolah siswa selalu dievaluasi dengan soal-soal matematika berpikir tingkat tinggi.

Adapun hasil wawancara antara peneliti (P) dengan guru (G) akan disajikan pada tabel berikut ini.

Tabel 2. Hasil Wawancara Peneliti dan Guru

P "Assalamu'alaikum wr,wb, Hari ini saya akan mewawancarai guru mata pelajaran matematika SMP Pondok Pesantren Ulul Albab Makassar. Setelah saya melihat dan menganalisis soal buatan Ibu dalam mengevaluasi siswa. Saya melihat rata-rata, Ibu menggunakan tingkatan soal C1, C2 dan C3. Apa kendala Ibu dalam membuat soal yang merangsang untuk berpikir tingkat tinggi ini?"

G "Pertama, Siswa saya itu kurang referensi, karena siswa disini kurang membaca buku Istilah matematika, sehingga siswa saya kurang mengerti 'Apa maksud dari masalah (soal) matematika tersebut'. Kedua, saya khawatir siswa tidak mampu menjawab karena setelah melihat kemampuan siswa saya dari kelas VII sampai sekarang, mereka mempunyai kemampuan yang kurang. jadi saya Cuma mengevaluasi mereka pada tingkatan soal C1, C2, dan C3 saja. Dan terakhir Tenaga pendidik belum bisa membedakan soal tingkatan rendah dan soal tingkatan tinggi, dikarenakan pendidik belum paham betul bentuk soal tersebut.

P "Dari kendala-kendala yang Ibu hadapi dalam membuat soal berpikir tingkat tinggi ini, Apa penyebab kendala tersebut?"

G "Penyebab kendala Ibu dalam membuat soal berpikir tingkat tinggi yaitu: Tidak adanya pelatihan yang diberikan kepada guruguru, khususnya guru matematika dalam membuat soal matematika berpikir tingkat tinggi ini. Jadi, perlulah kami sebagai guru untuk diberi pelatihan seperti itu untuk mengevaluasi hasil belajar siswa dari aspek C4, C5, dan C6. Agar tujuan Mata Pelajaran Matematika dalam Standar Isi pada Permendiknas Nomor 22 tahun 2006 yaitu agar siswa mampu memecahkan masalah matematika meliputi kemampuan memahami masalah, merancang model matematika, menyelesaikan model dan menafsirkan solusi yang diperoleh itu dapat tercapai."

P "Pertanyaan terakhir, Apa harapan Ibu tentang penggunaan soal matematika yang merangsang siswa untuk berpikir tingkat tinggi ini?"

G "Harapan saya tentang penggunaan soal matematika berpikir tingkat tinggi dapat digunakan dalam kegiatan evaluasi siswa, walaupun jawaban siswa sekarang agak kurang sempurna, diharapkan ketika siswa turun ke masyarakat, siswa dapat menyelesaikan permasalahan masyarakat karena di sekolah siswa selalu di evaluasi dengan soal-soal matematika berpikir tingkat tinggi".

$\mathrm{P} \quad$ "Terimakasih, Bu atas kesempatan yang di berikan. Semoga penggunaan soal matematika berpikir tingkat tinggi dapat diaplikasikan dalam evaluasi hasil belajar siswa ke depan, Assalamualaikum wr,wb".

G "Sama-sama, Wa'alaikum salam wr,wb". 


\section{Deskripsi Hasil Tes Kemampuan Pemecahan Masalah Siswa}

Berdasarkan hasil penelitian yang telah dilakukan di kelas VIII SMP Pondok Pesantren Ulul Albab Makassar yang dimulai sejak tanggal 21 Januari sampai dengan 1 April 2015, penulis dapat mengumpulkan data melalui instrumen tes dan memperoleh data hasil kemampuan pemecahan masalah berupa nilai siswa kelas VIII SMP Pondok Pesantren Ulul Albab Makassar.

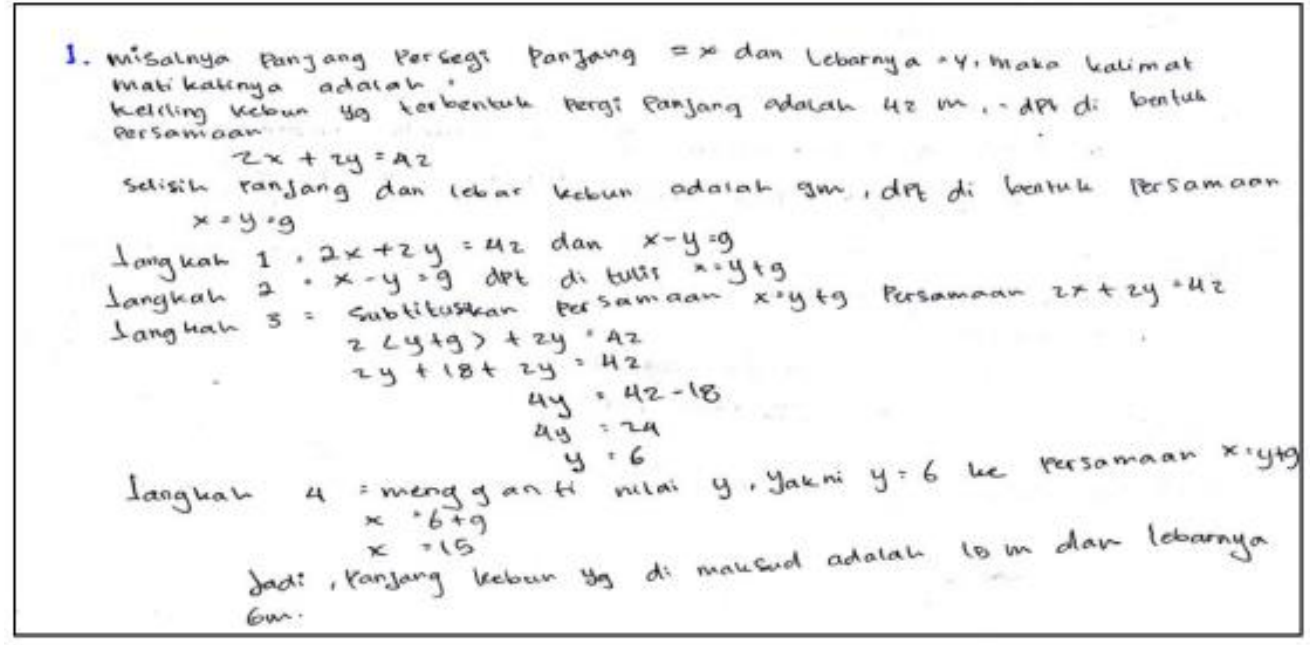

Gambar 3. Hasil Jawaban Tes Kemampuan Pemecahan Masalah Matematis Siswa

Hasil analisis dari jawaban siswa tersebut terlihat bahwa siswa memiliki kemampuan pemecahan masalah. Tampak dari jawabannya, siswa menuliskan apa yang diketahui dan apa yang ditanyakan dari soal dengan tepat. Siswa menyajikan urutan langkah penyelesaian yang benar dan mengarah pada jawaban yang benar, menggunakan prosedur tertentu yang benar dan hasil yang benar, dan melakukan pengecekan terhadap proses dan jawaban dengan tepat serta membuat kesimpulan yang benar. Berdasarkan jawaban tersebut memenuhi kriteria atau indikator kemampuan pemecahan masalah menurut Fikriani dan Nurva (2020).

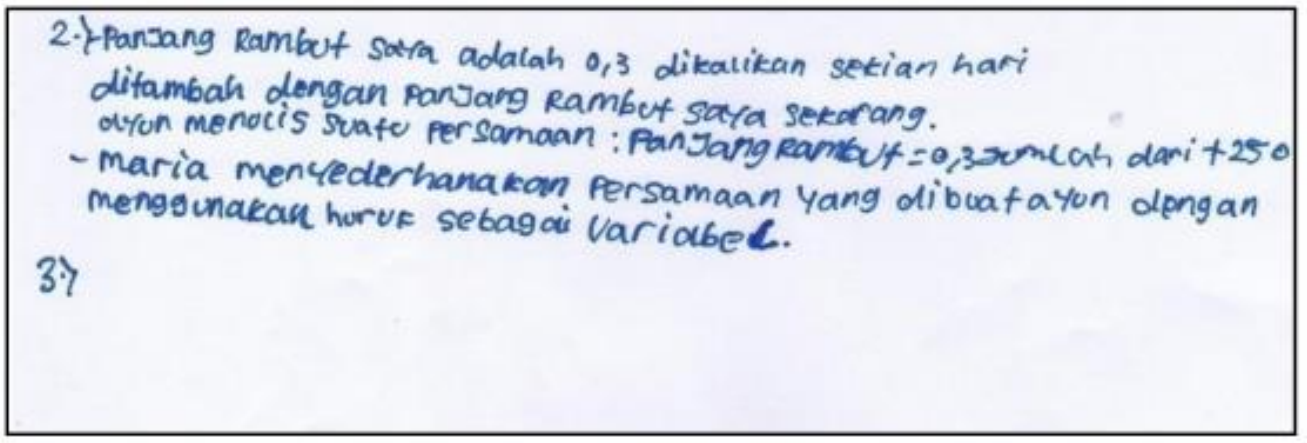

Gambar 4. Hasil Jawaban Tes Kemampuan Pemecahan Masalah Matematis Siswa

Berdasarkan jawaban siswa, terlihat bahwa kemampuan pemecahan masalah siswa sangat kurang karena hanya menuliskan pemahamannya terhadap masalah (soal) matematika yaitu membuat model persamaan masalah matematika. 


\section{SIMPULAN}

Berdasarkan hasil penelitian dan pembahasan sebelumnya, maka diperoleh beberapa kesimpulan sebagai berikut: (1) kemampuan guru dalam membuat soal yang merangsang siswa untuk berpikir tingkat tinggi masih kurang. Soal buatan guru matematika kelas VIII SMP Pondok Pesantren Ulul Albab Makassar didominasi pada aspek kognitif tingkat pemahaman (C2) dengan persentase 33,5\%, pengetahuan (C1) 34,3\%. Aplikasi (C3) 1,8\%, analisis (C4) 0,4\%, evaluasi (C5) 0,2\%, dan kreasi (C6) 1,6\%; (2) kemampuan pemecahan masalah siswa kelas VIII dengan persentase hasil tes kemampuan pemecahan masalah siswa sebesar $70 \%$ berada pada kategori kurang, 15\% berada pada kategori cukup, $20 \%$ pada kategori baik, dan $0 \%$ pada kategori sangat tinggi. Hal ini berarti bahwa rata-rata hasil kemampuan pemecahan masalah matematika siswa kelas VIII SMP Pondok Pesantren Ulul Albab Makassar berada pada kategori kurang.

Berdasarkan hasil penelitian ini, maka penulis menyarankan kepada pihak yang berkaitan dalam bidang pendidikan beberapa hal antara lain: (1) Diharapkan kepada guru agar selalu berlatih membuat soal-soal matematika yang merangsang untuk berpikir tingkat tinggi serta menerapkan pembelajaran kemampuan pemecahan masalah kepada siswa, agar kemampuan pemecahan masalah siswa dapat menjadi meningkat; (2) Diharapkan adanya pelatihan-pelatihan cara membuat soal-soal HOTS tipe soal openended, yang diberikan kepada guru-guru matematika agar guru bisa mengembangkan kemampuannya lagi dalam membuat soal matematika yang bervariasi dan merangsang siswa untuk berpikir tingkat tinggi untuk mengevaluasi siswa-siswanya.

Diharapkan bagi peneliti selanjutnya untuk mencari inovasi dalam pengembangan matematika sebagai rujukan dalam penelitian selanjutnya, agar lebih berbeda dari penelitian sebelumnya dan bisa menambah wawasan dan pengetahuan baru.

\section{DAFTAR PUSTAKA}

Amalia, A., \& Pujiastuti, H. (2020). Analisis Kemampuan Berpikir Tingkat Tinggi Pada Siswa YPWKS Cilegon dalam Menyelesaikan Soal Pola Bilangan. Wahana Didaktika, 18(3), 247-254.

Asrul, Ananda, R., \& Rosnita. (2014). Evaluasi Pembelajaran. Bandung: Citapustaka Media.

Azizah, R., Zaenuri, \& Kharisudin, I. (2020). Kemampuan pemecahan masalah matematika dalam menyelesaikan soal cerita siswa SMA. PRISMA : Prosiding Seminar Nasional Matematika, 3, 237-246.

Chabibah, L. N., Siswanah, E., \& Tsani, D. F. (2019). Analisis Kemampuan Pemecahan Masalah Siswa dalam Menyelesaikan Soal Cerita Barisan Ditinjau dari Adversity Quotient. PHYTAGORAS: Jurnal Pendidikan Matematika, 14(2), 199-210.

Fauzan, M., Gani, A., \& Syukri, M. (2017). Penerapan Model Problem Based Learning Pada Pembelajaran Materi Sistem Tata Surya Untuk Meningkatkan Hasil Belajar Siswa. Jurnal Pendidikan Sains Indonesia, 05(01), 27-35.

Fikriani, T., \& Nurva, M. S. (2020). Analisis kemampuan pemecahan masalah siswa SMP Kelas IX dalam menyelesaikan soal matematika tipe Higher Order Thinking Skill (HOTS). AKSIOMA: Jurnal Matematika Dan Pendidikan Matematika, 11(2), 252-266.

Hidayati, A. U. (2017). Melatih Keterampilan Berpikir Tingkat Tinggi dalam Pembelajaran Matematika Pada Siswa Sekolah Dasar. TERAMPIL: Jurnal Pendidikan Dan Pembelajaran Dasar, 4(20), 143-156. 
Intan, F. M., \& Kuntarto, E. (2020). Kemampuan Siswa dalam Menyelesaikan Soal HOTS (Higher Order Thinking Skills) pada Pembelajaran Matematika di Kelas V Sekolah Dasar. Jurnal Pendidikan Dasar Indonesia, 5(1), 6-10.

Mita, D. S., Tambunan, L. R., \& Izzati, N. (2019). Analisis Kemampuan Pemecahan Masalah Peserta Didik dalam Menyelesaikan Soal PISA. Lentera Sriwijaya: Jurnal Ilmiah Pendidikan Matematika, 1(2), 25-33.

Nursalam, Angriani, A. D., Darmawati, Baharuddin, \& Aminuddin. (2018). Developing Test Instruments for Measurement of Students' High-Order Thinking Skill on Mathematics in Junior High School in Makassar. Journal of Physics: Conference Series, 1028(012169), 1-5. https://doi.org/10.1088/1742-6596/1028/1/012169

Pradani, S. L., \& Ilman, M. (2019). Analisis Kemampuan Pemecahan Masalah Siswa dalam Menyelesaikan Soal Matematika Tipe Higher Order Thinking Skill ( HOTS ). Jurnal Kreano : Jurnal Matematika Kreatif-Inovatif, 10(2), 112-118.

Rame, A. Y. F., \& Afri, L. D. (2020). Analisis Kemampuan Pemecahan Masalah Matematis Siswa dalam Menyelesaikan Soal Materi Barisan dan Deret. AXIOM: Jurnal Pendidikan \& Matematika, 09(2), 175-187.

Riati, T., \& Farida, N. (2017). Pengaruh Model Pembelajaran Quantum Learning Terhadap Kemampuan Pemecahan Masalah Matematika Siswa Kelas VIII SMP PGRI 02 Ngajum. Pi: Mathematics Education Journal, 1(1), 15-21. https://doi.org/10.21067/pmej.v1i1.1999

Sapitri, Y., Utami, C., \& Mariyam. (2019). Analisis Kemampuan Pemecahan Masalah Matematis Siswa dalam Menyelesaikan Soal Open-Ended pada Materi Lingkaran Ditinjau dari Minat Belajar. Jurnal Variabel, 2(1), 16-23.

Wardani, A. K. (2020). Kemampuan Berpikir Tingkat Tinggi Siswa SMP dalam Menyelesaikan Soal Matematika Model PISA. Jurnal Pendidikan Matematika, 14(1), $15-24$. 